\title{
Thermostatic cover for improving energy and technological efficiency of steel mills
}

\author{
Konstantin Strogonov ${ }^{1,}$, Sergey Tolkanov ${ }^{1}$, Karina Korkots $^{1}$, and Alexander Fedyukhin ${ }^{1}$ \\ ${ }^{1}$ National Research University Moscow Power Engineering Institute, Krasnokazarmennaya Ulitsa \\ 111250, 14, Moscow
}

\begin{abstract}
The article proposes a technical solution for reducing the energy costs of casting process and providing more stable production conditions, specifically, the use of a thermostatic cap. Two variants of steel casting are considered: with and without the application of a thermostatic cover using the example of a bucket with a capacity of six tons of steel. The technical challenge is to reduce heat losses through the bucket neck to ensure the stability of the melting temperature throughout the casting and to reduce the temperature of metal release from the steelmaking unit. The design of the thermostatic cover with specifications, as well as the duration of process steps in the steel casting with and without the use of a thermally insulated cap are described. The balance calculations were carried out using MathCAD environment, which confirmed significant energy savings with a slight increase in casting time associated with the appearance of an additional technological operation for installing the thermostatic cover after pouring. Using ANSYS Academic software, a study was carried out on the thermal fields of the ladle and steel at various stages of casting for two options, which confirmed the effectiveness of using a thermostatic cover.
\end{abstract}

\section{Introduction}

Currently in Russian Federation and other countries there is a tendency to increase steel production, according to World Steel Association. In 1970, 600 million tons were produced, in 2000 - 850 million tons, in 2010 production amounted to almost 1.414 billion tons, and in $2016-1.628$ billion tons [1]. At the same time, the requirements for the quality of steel and the reduction of energy costs for the production of steel products are constantly growing. This article discusses one of the variants to reduce energy costs for the production of foundry products and providing more stable conditions for the casting process.

Steel-casting ladles are used at ferrous metallurgy enterprises for transportation and for pouring liquid steel in volumes from 0.5 to 480 tons [2-4]. Thermostatic cover are widely

\footnotetext{
* Corresponding author: $\underline{\text { strogonovkv@yandex.ru }}$
} 
used in large enterprises with a full metallurgical cycle while at foundries with a capacity of less than 1 million tons of steel per year, this solution is rarely used [5]. Today in the world there are about 1000 mini-plants of various capacities and level of technology, which produce more than $15 \%$ of metal [6]. Meanwhile, at insignificant expenses for the application of this solution, significant effects are achieved [7, 8].

\section{Materials and Methods}

In this paper, as an example, a ladle with a refractory lining of 6 tons was taken, shown in figure 1, as well as a thermostatic cover made using high-temperature insulation, shown in figure 2. A feature of such ladle, in contrast to larger units, is their high specific surface area. For this reason, the heat loss of the metal in low-capacity ladle is higher, than in

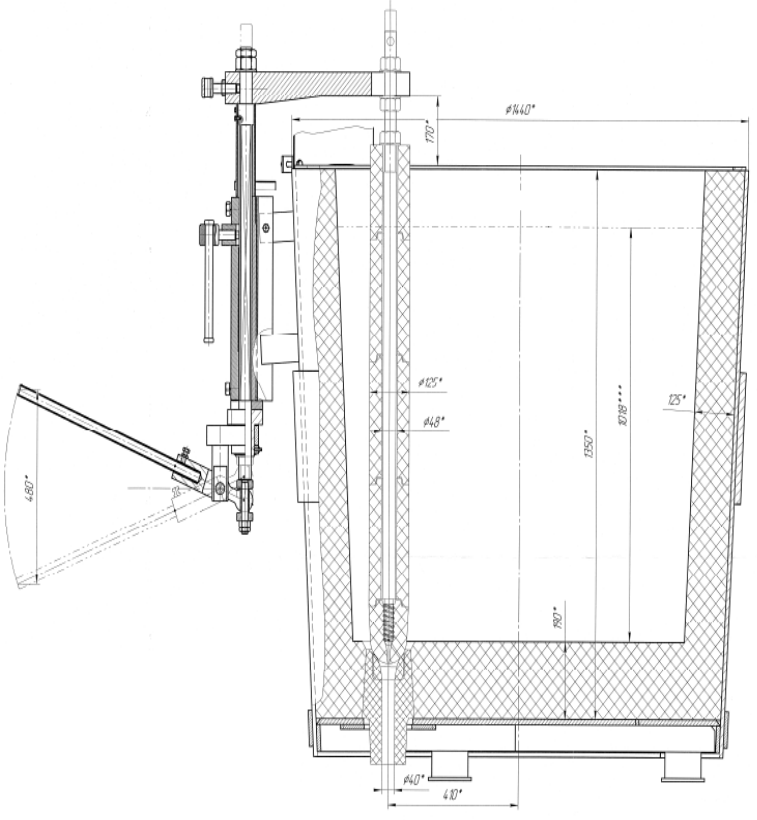

Fig 1. Locking pouring steel ladle.

large [9]. The cooling rate of the metal in such buckets is 1.5-2 times higher than that for large ladle, which means the relevance of using thermostatic caps is higher.

Losses of heat from the ladle lead to a decrease in the temperature of the liquid metal, accordingly, its additional overheating is required in an electric arc steel-smelting furnace (up to $1600-1650^{\circ} \mathrm{C}$ and higher) [10], this leads to a deterioration of the properties of steel products. The number of defects increases from overheated or supercooled metal in the case when the metal is cooled during casting $[11,12]$.

The object of the study is a 6-ton steel-teeming ladle, which has a conical shape with a height of 1.507 meters and an outer diameter of 1.44 meters. The ladle is filled with liquid steel at 1.018 meters from the bottom. The side wall with a thickness of 0.125 meters consists of three layers of different refractories [13]. 


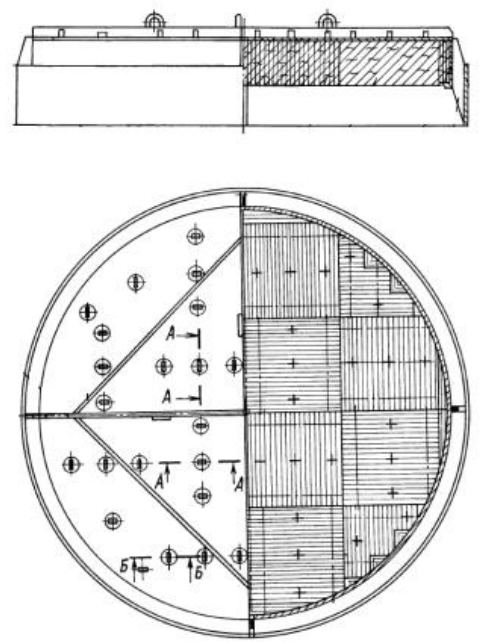

Fig 2. Thermostatic cover

After spillage the ladle is covered with a thermostatic cover, consisting of a steel frame with a thickness of $20 \mathrm{~mm}$, covered with fiber refractory material with a thickness of 25 $\mathrm{mm}$.

The thermophysical properties of the liquid steel, slag, steel shell and refractory materials, used in the calculation are shown in Table $1[4,14-16]$.

Table 1. The thermophysical properties of the liquid steel, slag, steel shell and refractory materials

\begin{tabular}{|l|c|c|c|}
\hline \multicolumn{1}{|c|}{ Material } & $\begin{array}{c}\text { Thermal } \\
\text { conductivity } \boldsymbol{\lambda}, \\
\mathbf{W} /(\mathbf{m ~ K} \text { })\end{array}$ & $\begin{array}{c}\text { Density } \mathbf{\rho}, \\
\mathbf{k g} / \mathbf{m}^{\mathbf{3}}\end{array}$ & $\begin{array}{c}\text { Specific heat } \mathbf{C}_{\mathbf{p}}, \\
\mathbf{J} / \mathbf{( k g ~ K )}\end{array}$ \\
\hline $\begin{array}{l}\text { Periclase bricks (GOST } \\
\text { 4689-74) }\end{array}$ & 1.98 & 2700 & 1514 \\
\hline $\begin{array}{l}\text { Mullite-siliceous } \\
\text { bricks (GOST 24704-81) }\end{array}$ & 1.34 & 2200 & 1183 \\
\hline $\begin{array}{l}\text { Asbestos chrysolite fluff } \\
\text { (TU 21-22-10-72) }\end{array}$ & 0.218 & 450 & 850 \\
\hline Steel (casing) & 50 & 7800 & 480 \\
\hline Liquid steel & 30 & 6750 & 800 \\
\hline Slag & 3 & 3000 & 2090 \\
\hline $\begin{array}{l}\text { Multisiliceous fiber } \\
\text { (cover) }\end{array}$ & 0.13 & 200 & 1075 \\
\hline
\end{tabular}

\section{Results}


To evaluate the energy effect, two casting options were considered, the first option pouring without using a thermostatic cover, the second option using the thermostatic cover. Technological operations carried out with a ladle are shown in Table 2.

Table 2. Duration of technological operations

\begin{tabular}{|c|c|c|c|c|c|}
\hline No. & $\begin{array}{c}\text { Version } 1 . \\
\text { Existing position }\end{array}$ & Time, min & No. & $\begin{array}{l}\text { Version } 2 . \\
\text { Pouring without using } \\
\text { the thermostatic cover }\end{array}$ & Time, min \\
\hline 1. & $\begin{array}{l}\text { Drain metal into } \\
\text { the ladle }\end{array}$ & 2.5 & 1. & $\begin{array}{l}\text { Drain metal into the } \\
\text { ladle }\end{array}$ & 2.5 \\
\hline 2. & $\begin{array}{l}\text { Elevation the } \\
\text { filled ladle to the } \\
\text { transport position }\end{array}$ & 0.7 & 2. & $\begin{array}{l}\text { Elevation the filled } \\
\text { ladle to the transport } \\
\text { position }\end{array}$ & 0.7 \\
\hline 3. & $\begin{array}{l}\text { Transporting the } \\
\text { ladle to the } \\
\text { temperature } \\
\text { measurement } \\
\text { point }\end{array}$ & 1 & 3. & $\begin{array}{l}\text { Transporting the ladle } \\
\text { to the temperature } \\
\text { measurement point }\end{array}$ & 0.7 \\
\hline 4. & $\begin{array}{l}\text { Temperature } \\
\text { measurement }\end{array}$ & 1 & 4. & $\begin{array}{l}\text { Temperature } \\
\text { measurement } \\
\text { (Measurement is } \\
\text { performed in parallel } \\
\text { with the work on the } \\
\text { hook detaching from the } \\
\text { ladle, engaging and } \\
\text { elevation the } \\
\text { thermostatic cover) }\end{array}$ & 1 \\
\hline 5. & $\begin{array}{l}\text { Transportation } \\
\text { ladle to the place } \\
\text { of pouring }\end{array}$ & 3.8 & 5. & $\begin{array}{l}\text { Crane operation for } \\
\text { installing the } \\
\text { thermostatic cover } \\
\text { (disengaging the hook } \\
\text { from the ladle, elevation } \\
\text { and installing the } \\
\text { thermostatic cover }\end{array}$ & 5.3 \\
\hline \multirow[t]{2}{*}{6.} & \multirow[t]{2}{*}{ Time pouring } & \multirow[t]{2}{*}{9} & 6. & $\begin{array}{l}\text { Transporting the ladle } \\
\text { to the temperature } \\
\text { measurement point }\end{array}$ & 3.8 \\
\hline & & & 7. & Time pouring & 9 \\
\hline \multicolumn{2}{|c|}{ Total time } & 18 & \multicolumn{2}{|c|}{ Total time } & 22 \\
\hline
\end{tabular}

Table 3 presents the results of calculations carried out in MathCAD environment to reduce the temperature of the steel in the ladle and the heat loss performed according to the formulas and methods reflected in the literature [17-19]. The use of a thermostatic cover has affected the total time of the process, held with a ladle for 5 minutes, which undoubtedly increased heat loss during additional crane operations at the time of installing the thermostatic cover on the ladleFrom the obtained results it can be seen that the main heat losses are higher in the variant without the use of a cover, due to the larger share of losses through the slag. The final temperature of the metal is higher in the version with a cover. Despite the increase in time, the total heat loss using the lid decreased by 184.69 MJ, and the final temperature of the metal at the end of casting increased by $87.15^{\circ} \mathrm{C}$. 
Table 3. Temperature and heat losses during manufacturing operations

\begin{tabular}{|c|c|c|c|c|c|c|c|c|}
\hline Parameters & $\begin{array}{c}\text { Drain } \\
\text { metal }\end{array}$ & $\begin{array}{c}\text { levation } \\
\text { ladle }\end{array}$ & Transport & $\begin{array}{c}\text { Temperature } \\
\text { measurement }\end{array}$ & $\begin{array}{c}\text { Installing the } \\
\text { thermostatic } \\
\text { cover }\end{array}$ & Transport & Pouring & $\begin{array}{l}\text { Total } \\
\text { loss }\end{array}$ \\
\hline $\begin{array}{c}\text { Temperature } \\
\text { loss without } \\
\text { cover, }{ }^{\circ} \mathrm{C}\end{array}$
\end{tabular}

Calculations show that when metal is released from a steel-smelting furnace with a temperature of $1600^{\circ} \mathrm{C}$, the metal is cooled to a temperature below permissible at $1520^{\circ} \mathrm{C}$, this means that the products will have defects associated with the low fluidity of steel. To do this, the staff is forced to overheat the metal in accordance with the calculations at $87.15^{\circ} \mathrm{C}$. In the variant with the use of a cover, the metal is cooled to $1526.67^{\circ} \mathrm{C}$, that ensures optimum pouring temperature throughout the pouring process. This step will reduce the temperature difference from the moment the metal is released to the end of pouring, which will reduce the number of scraps in production and ensure the stability of quality [20].

To verify the calculated data, we simulated the thermal state of the ladle during the pouring period.

When taking into account the influence of the thermal state of the ladle on the heat loss of the metal, the model takes into account the influence of radiant and convective heat exchange, and thermal conductivity between the surfaces of the ladle. To determine the decrease in temperature of the liquid steel from the beginning to the end of the casting, all heat losses for this period were taken into account, which consist of:

- heat loss by heat conduction through the walls of the ladle;

- heat losses by convection and radiation from the ladle casing and cover;

- heat loss by radiation from the slag mirror covering the metal.

The formulation of the problem of numerical investigation and determination of the boundary conditions was carried out in ANSYS Academic Student Release modules ANSYS Fluent and ANSYS CFX. Processing and analysis of the results were also carried out in the ANSYS environment.

Figure 3 shows two variants of the ladle (with and without cover) at full load of $100 \%$. The temperature of the melt at the beginning of this stage, respectively, is $1531{ }^{\circ} \mathrm{C}$ for a ladle with a cover and $1540^{\circ} \mathrm{C}$ for a ladle without a cover calculated in the second chapter. The temperature of the slag in the embodiment with a cover below $5.6^{\circ} \mathrm{C}$. 

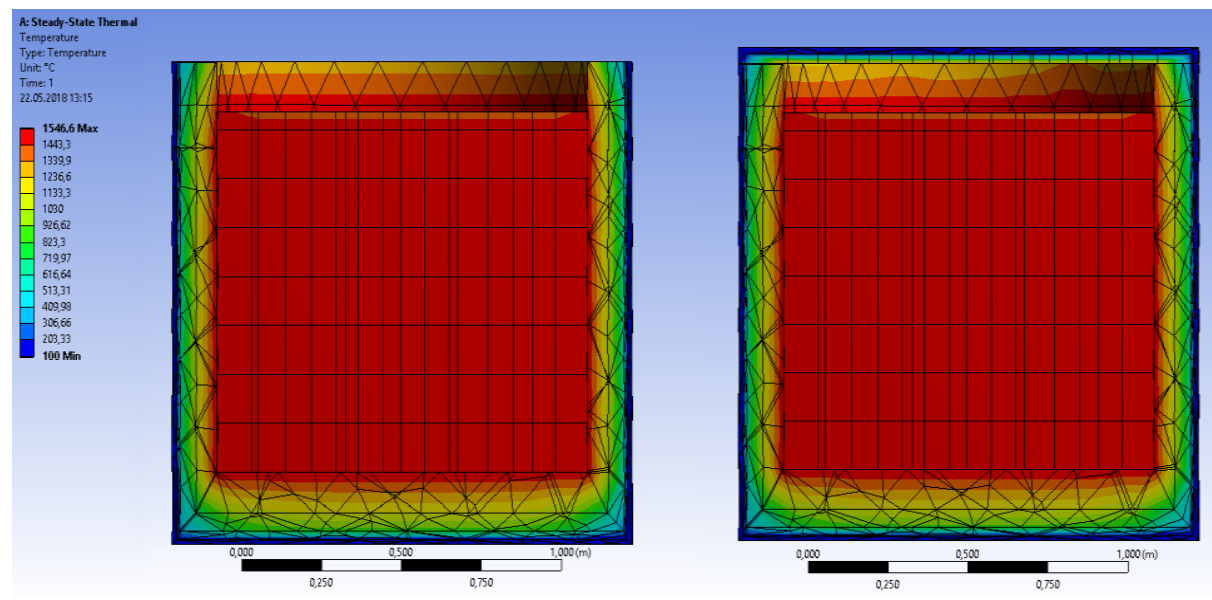

Fig. 3. Temperature field at a melt level of $100 \%$

Figure 4 shows two variants under load ladle $75 \%$. Melt temperature in a ladle without cover $\left(1536.1^{\circ} \mathrm{C}\right)$ slightly lower than the temperature in the ladle with a cover $\left(1537.1^{\circ} \mathrm{C}\right)$. The figure shows that the temperature of the inner walls of the ladle with a cover is higher than in the first embodiment. The slag temperature is also higher in the second version $\left(1423.86^{\circ} \mathrm{C}\right)$. All temperatures are close to the calculated data.
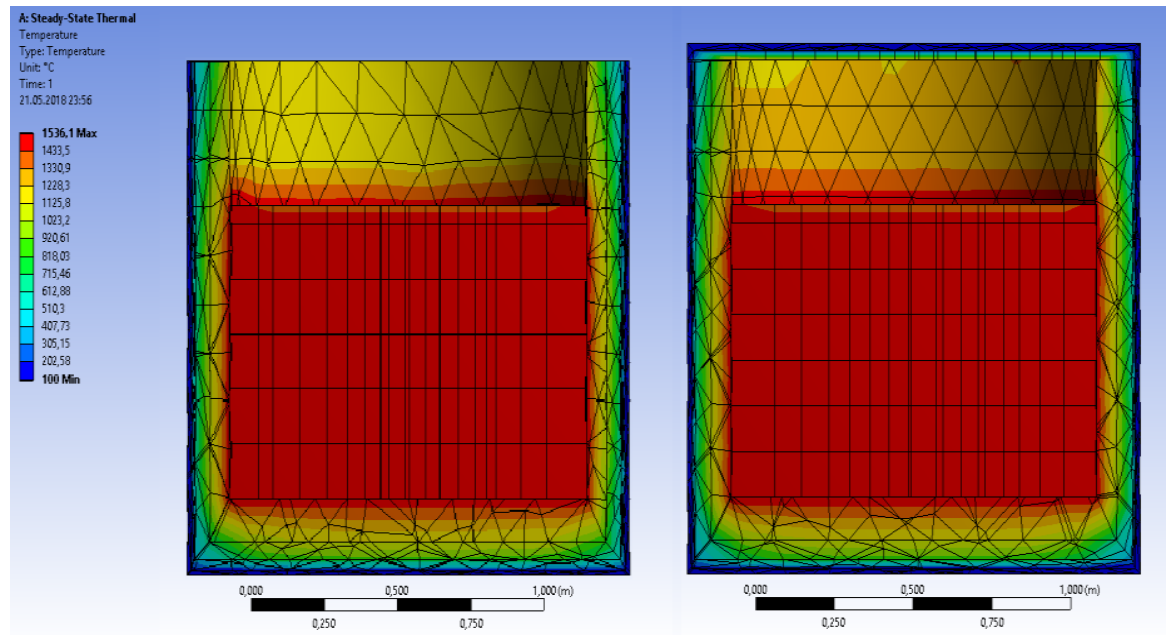

Fig. 4. Temperature field at a melt level of $75 \%$

Figure 4 shows two variants under load ladle $50 \%$. Melt temperature in a ladle without lid $\left(1513.2^{\circ} \mathrm{C}\right)$ lower than the temperature in the ladle with a cover $\left(1536.5^{\circ} \mathrm{C}\right)$ by $23.3{ }^{\circ} \mathrm{C}$. The figure shows that the temperature of the inner walls of the bucket with a lid is higher than in the first embodiment. The slag temperature is also higher in the second version. $\left(1423.21^{\circ} \mathrm{C}\right)$ by $17.91^{\circ} \mathrm{C}$. 


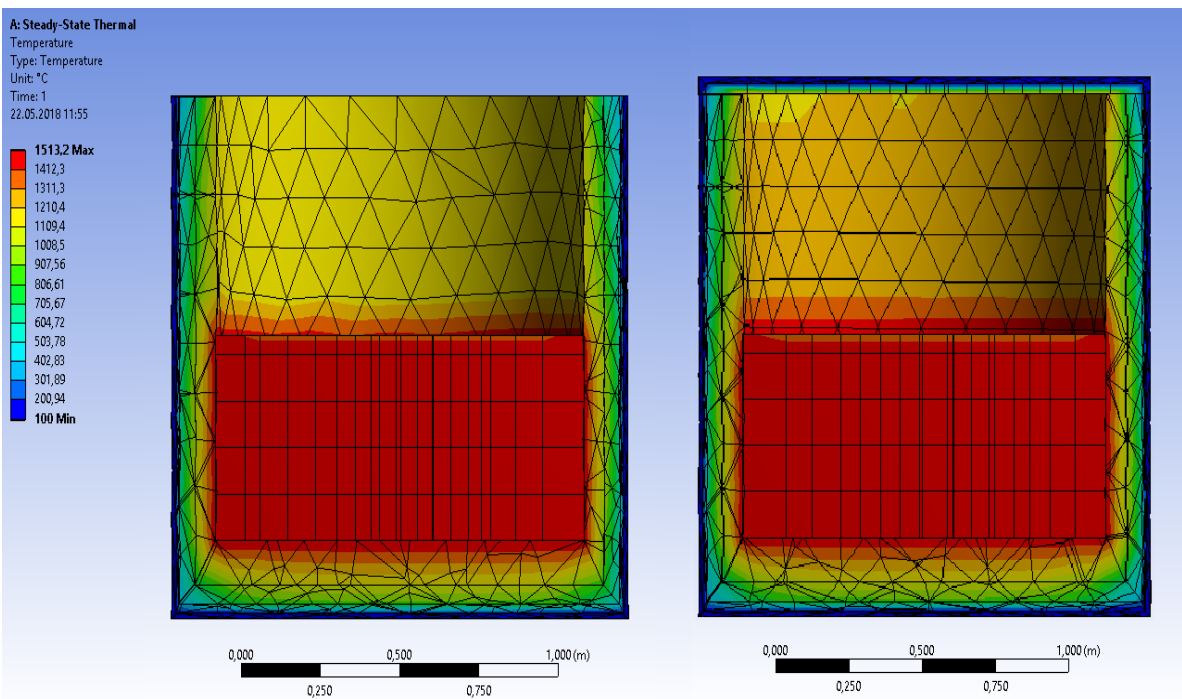

Fig. 5. Temperature field at a melt level of $50 \%$

Figure 4 shows two variants under load ladle $25 \%$. Melt temperature in a ladle without cover $\left(1489.4^{\circ} \mathrm{C}\right)$ lower than the temperature in the ladle with a cover $\left(1535.4^{\circ} \mathrm{C}\right)$ by $46^{\circ} \mathrm{C}$. The figure shows that the temperature of the inner walls of the ladle with a cover is also higher, as in the previous stages. The slag temperature is higher in the second version. $\left(1422.35^{\circ} \mathrm{C}\right)$ by $39.95^{\circ} \mathrm{C}$.

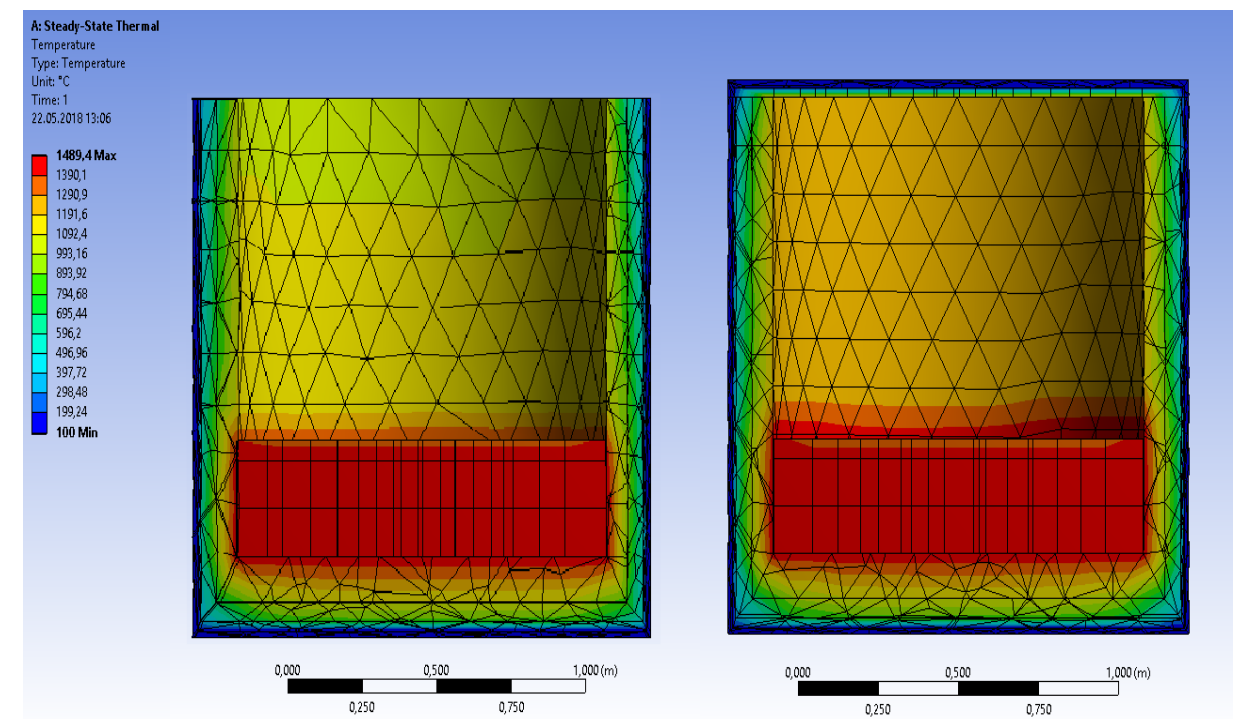

Fig. 6. Temperature field at a melt level of $25 \%$

\section{Discussion}

Thus, numerical simulation of steel casting made it possible to get an idea of the state of the melt in the ladle space, determine melt temperatures and ladle and cover surfaces. The 
results of modeling the temperature of the metal for a variant of casting the stele without the use of a thermostatic cover are shown in Table 4.

Table 4. The results of the simulation for the ladle with no cover

\begin{tabular}{|l|r|r|r|r|}
\hline \multirow{2}{*}{ Parameters } & \multicolumn{4}{|c|}{ Ladle loading } \\
\cline { 2 - 5 } & \multicolumn{1}{|c|}{$\mathbf{1 0 0 \%}$} & \multicolumn{1}{c|}{$\mathbf{7 5 \%}$} & \multicolumn{1}{|c|}{$\mathbf{5 0 \%}$} & \multicolumn{1}{c|}{$\mathbf{2 5 \%}$} \\
\hline The estimated temperature of the melt, ${ }^{\circ} \mathrm{C}$ & 1540.00 & 1527.00 & 1510.00 & 1485.00 \\
\hline Simulated melting temperature, ${ }^{\circ} \mathrm{C}$ & 1540.00 & 1536.10 & 1513.20 & 1489.40 \\
\hline $\begin{array}{l}\text { The estimated temperature of the outer wall of } \\
\text { the ladle, }{ }^{\circ} \mathrm{C}\end{array}$ & 99.39 & 99.41 & 99.43 & 99.46 \\
\hline $\begin{array}{l}\text { The simulated temperature of the outer wall of } \\
\text { the ladle, }{ }^{\circ} \mathrm{C}\end{array}$ & 102.60 & 104.40 & 106.20 & 108.50 \\
\hline The calculated temperature of the slag surface, ${ }^{\circ} \mathrm{C}$ & 1426.00 & 1414.00 & 1398.00 & 1376.00 \\
\hline Simulated slag surface temperature, ${ }^{\circ} \mathrm{C}$ & 1430.20 & 1420.60 & 1405.30 & 1382.40 \\
\hline
\end{tabular}

In Table 5 shows the results of modeling temperature changes for the variant with the use of a thermostatic cover.

Table 5. Simulation results for ladle with cover

\begin{tabular}{|l|r|r|r|r|}
\hline \multirow{2}{*}{ Parameters } & \multicolumn{4}{|c|}{ Ladle loading } \\
\cline { 2 - 5 } & \multicolumn{1}{|c|}{$100 \%$} & \multicolumn{1}{c|}{$75 \% \%$} & \multicolumn{1}{c|}{$50 \%$} & \multicolumn{1}{c|}{$25 \%$} \\
\hline The estimated temperature of the melt, ${ }^{\circ} \mathrm{C}$ & 1531.00 & 1531.00 & 1530.00 & 1529.00 \\
\hline Simulated melting temperature, ${ }^{\circ} \mathrm{C}$ & 1531.00 & 1530.80 & 1529.6 & 1528.30 \\
\hline $\begin{array}{l}\text { The estimated temperature of the outer wall of the } \\
\text { ladle, }{ }^{\circ} \mathrm{C}\end{array}$ & 99.39 & 99.49 & 99.41 & 99.40 \\
\hline $\begin{array}{l}\text { The simulated temperature of the outer wall of the } \\
\text { ladle, }{ }^{\circ} \mathrm{C}\end{array}$ & 102.60 & 104.40 & 106.20 & 108.50 \\
\hline Estimated surface temperature of the cover, ${ }^{\circ} \mathrm{C}$ & 91.49 & 102.83 & 117.94 & 139.16 \\
\hline Simulated cover surface temperature,${ }^{\circ} \mathrm{C}$ & 92.60 & 105.40 & 120.63 & 140.20 \\
\hline The calculated temperature of the slag surface,,${ }^{\circ} \mathrm{C}$ & 1418.44 & 1417.91 & 1417.19 & 1416.00 \\
\hline Simulated slag surface temperature, ${ }^{\circ} \mathrm{C}$ & 1424.6 & 1423.86 & 1423.21 & 1422.35 \\
\hline
\end{tabular}

The results of the work for the conditions of the steel bucket with a capacity of 6 tons, lead to the following conclusions:

1. The use of thermostatic covers will reduce the total heat loss from the ladle by 184.69 MJ during the period of transportation and casting of steel from the ladle;

2. Reduction of heat losses will allow to reduce the temperature of metal overheating in the furnace by $87.15^{\circ} \mathrm{C}$;

3. Reduction of the temperature difference between the metal in the casting will reduce manufacturing defects.

\section{References}

1. https://www.worldsteel.org/steel-by-topic/statistics/global-map.html (Last accessed: 22.05.2018).

2. A. M. Zborshchik, Abstract of lectures on the subject "Metallurgy of steel", 238 (Donetsk: State University "DonNTU", 2008)

3. V. A. Kudrin, Theory and technology of steel production: A textbook for universities, 528 (Moscow, "Mir", LLC "Publishing house AST", 2003) 
4. V. G. Voskoboynikov, and etc., General metallurgy - 6 - pub., Revised and additional, 768 (Moscow, IKTs "Akademkniga", 2005)

5. I. M. Bershitsky, Insulating bucket cover: pat. 2211112 RU: MPK 7 B 22 D 41/00 /; applicant and patent holder Bershitsky I. M. № 2001128012/02; appl. 17.10.2001; publ. 27.08.2003

6. A. N. Smirnov, V. M. Safonov, L. V. Dorokhova, A. Yu. Tsuprun, Metallurgical miniplants, 469 (Donetsk, Nord-Press, 2005)

7. M. A. Murikov, A. I. Nosovets, V. M. Nosovets, A. V. Olenchenko, I. I. Shkulkova, Use of heat-shielding covers for steel-teeming ladles at RUE "BMZ", Casting and metallurgy, 1(45) (2008)

8. Z. K. Kabakov, D. I. Borodin, N. E. Khisamutdinov, M. A. Pakholkova, Thermal technical substantiation of the thermal insulation of the lid for the casting ladle, Herald of Cherepovets State University, №2, T.1 (2012)

9. G. M. Borodulin, E. I. Moshkevich, Stainless steel, 319 (Moscow, Metallurgy, 1973)

10. A. V. Egorov, Calculation of power and parameters of electric furnaces of ferrous metallurgy. Training manual for universities, 280 (Moscow, Metallurgy, 1990)

11. Y. F. Voronin, V. A. Kamaev, Atlas of casting defects. Black alloys, 327 (Monograph. Moscow, "Mechanical Engineering - 1», 2005)

12. V. K. Mogilyov, O. I. Lev, Reference caster, 272 (Moscow, Mechanical Engineering, 1988)

13. V. S. Starikov, Refractories and linings in ladle metallurgy: a manual for universities (Moscow, MISiS publishing house, 2003)

14. http://www.teplopromproekt.ru/about/articles/ sovremennayavysokotemperaturnayaizolyatsiya-stalerazlivochnykh-kovshey/ (Last accessed 27.04.2019)

15. G. G. Abramov, Reference book of the young caster: Casting in sandy-clay forms. Reference for avg. Prof.-tech. studies. Institutions, 199 (Moscow, Higher. school, 1978)

16. B. S. Mastryukov, Theory, design and calculations of metallurgical furnaces. Calculations of metallurgical furnaces: account. for technical schools; in $2 \mathrm{~m}$. -2 nd ed., revised, and add, 376 (Moscow, Metallurgy, 1986)

17. V. P. Isachenko, V. A. Osipova, A. S. Sukomel, Heat transfer: A textbook for universities, ed. 4th, revised, and additional, 416 (Moscow, Energoizdat, 1981)

18. V. P. Pishchulin, Calculation of heat loss to the environment: a tutorial, 31 (Seversk: Publishing House SGTA, 2009)

19. E. A. Krasnoshchekov, A. S. Sukomel, A heat transfer logbook, 288 p., 136 p. (Moscow, Energy, 1980, 1997)

20. C. V. Tolkanov, K. V. Strogonov, Study on the use of a thermostating cover for a steelteeming ladle with a volume of 6 tons and calculation of the resulting energy effect, XXIV International Scientific and Technical Conference "Radio electrical and electrical engineering and energy" 638.p. (2018) 